\title{
Yenidoğan Döneminde Nöron Spesifik Enolaz Yüksekliği ile Seyreden Atipik (Selüler) Konjenital Mezoblastik Nefroma Olgusu
} A Case of Atypical (Cellular) Congenital Mesoblastic Nephroma Presenting
with High Serum Levels of Neuron Specific Enolase in Neonatal Period

Nihan Hilal Hoşağası, Dilek Dilli, İsmet Faruk Özgüner*, Gürses Şahin**, Esin Cengiz Boduroğlü** , Banu Aydın, Nuran Üstün, Aysegül Zenciroğlu, Nurullah Okumuş, Burak Özkan****

Dr. Sami Ulus Kadın Doğum ve Çocuk Hastalıkları Eğitim ve Araştırma Hastanesi, Yenidoğan Kliniği, Ankara, Türkiye

*Dr. Sami Ulus Kadın Doğum ve Çocuk Hastalıkları Eğitim ve Araştırma Hastanesi, Çocuk Cerrahisi Kliniği, Ankara, Türkiye

**Dr. Sami Ulus Kadın Doğum ve Çocuk Hastalıkları Eğitim ve Araştırma Hastanesi, Onkoloji Kliniği, Ankara, Türkiye

***Dr. Sami Ulus Kadın Doğum ve Çocuk Hastalıkları Eğitim ve Araştırma Hastanesi, Patoloji Bölümü, Ankara, Türkiye

****Dr. Sami Ulus Kadın Doğum ve Çocuk Hastalıkları Eğitim ve Araştırma Hastanesi, Radyoloji Kliniği, Ankara, Türkiye

\section{Özet}

Yenidoğan döneminde en sık görülen abdominal kitle nedenleri nöroblastom, germ hücreli tümörler, hepatoblastom ve konjenital mezoblastik nefromadır. Konjenital mezoblastik nefroma (KMN) yaşamın ilk üç ayında görülen tüm renal tümörlerin \%90'ını oluşturur. Total eksizyon veya nefrektomi tedavi için yeterlidir. Nöron spesifik enolaz esas olarak nöronların sitoplazmasında bulunan glikolitik bir enzimdir. Özellikle nöroblastom ve küçük hücreli akciğer kanserler için duyarlııı̆ı yüksektir. Bu yazıda abdominal kitle saptanan, ultrasonografik olarak kitlenin kalsifiye olması ve serum nöron spesifik enolaz düzeyi yüksekliği nedeniyle nöroblastom düşünülen, ancak histopatolojik incelemeyle atipik (selüler) konjenital mezoblastik nefroma tanısı alan bir yenidoğan olgu sunuldu. (Haseki Tıp Bülteni 2014; 52: 223-6)

Anahtar Sözcükler: Konjenital mezoblastik nefroma, yenidoğan
The most common causes of abdominal mass are neuroblastoma, germ cell tumors, hepatoblastoma and congenital mesoblastic nephroma. Congenital mesoblastic nephroma (CMN) accounts for more than $90 \%$ of all renal tumors seen in the first three months of life. Total nephrectomy is curative. Neuron-specific enolase is a glycolytic enzyme that is localized primarily to the neuronal cytoplasm. Its sensitivity is especially high for neuroblastoma and small cell lung cancer. In this paper, we report a newborn with abdominal mass that was firstly considered as neuroblastoma due to calcifications observed on ultrasonography and high levels of serum neuron-specific enolase. After histopathological evaluation of the lesion, the patient was diagnosed as having atypical (cellular) congenital mesoblastic nephroma. (The Medical Bulletin of Haseki 2014; 52: 223-6)

Key Words: Congenital mesoblastic nephroma, newborn
Yazışma Adresi/Address for Correspondence: Dilek Dilli

Dr. Sami Ulus Eğitim ve Araştırma Hastanesi, Yenidoğan Kliniği, Ankara, Türkiye Tel.: +90 3123056230 E-posta: dilekdilli2@yahoo.com

Geliş Tarihi/Received: 15 Aralık 2013 Kabul Tarihi/Accepted: 04 Şubat 2014 published by Galenos Publishing. 


\section{Giriş}

Çocukluk döneminde abdominal kitle görülmesi sık karşılaşılan bir durum değildir ve sıklıkla kötü huylu bir hastalık bulgusudur. Yenidoğanda görülen kitlelerin ise ancak küçük bir bölümü (\%15'i) kötü huyludur. Yenidoğan döneminde en sık görülen kötü huylu tümörler nöroblastom ve germ hücreli tümörler olup bunları hepatoblastom izler (1). Nöroblastoma, adrenal medulla veya sempatik ganglionlarda normalde bulunan primordial nöral krest hücrelerinden köken alan bir tümördür. Fizik muayene ve görüntüleme yöntemlerinin yanı sıra biyokimyasal tetkikler laktik dehidrogenaz, ferritin, nöron spesifikenolaz (NSE) ve idrarda katekolamin metabolitlerinin tayini (vanilmandelikasit; VMA, homovalinikasit; HVA) tanıda yol göstericidir. NSE nöronların sitoplazması ve periferal santral nöroendokrin hücrelerde bulunan bir enzimdir. Özellikle nöroblastoma ve küçük hücreli akciğer kanserler için duyarlılığı yüksektir.

Konjenital mezoblastik nefroma (KMN) ilk defa 1967 yılında Bolande ve ark. (2) tarafından tanımlanmıştır. KMN metanefrik blastemden kaynaklanan mezenkimal bir neoplazmdır. KMN yenidoğan ve üç ayın altındaki çocuklarda en sık görülen iyi huylu renal neoplazmdır. Tüm çocukluk çağı tümörlerinin \%3-\%10'unu oluşturur (3). En sık görülen belirti ve bulgular abdominal kitle, hematüri, polihidramniyoz, hidrops ve prematüritedir $(4,5)$. KMN'nin kesin tanısı histopatolojik inceleme ile konulmaktadır.

Bu yazıda abdominal kitle ile prezente olan, ultrasonografik olarak kitlenin kalsifiye olması ve serum NSE düzeylerinin yüksek olması nedeniyle nöroblastom düşünülen ancak histopatolojik olarak selüler KMN tanısı alan prematüre bir yenidoğan olgu sunuldu.

\section{Olgu}

Yirmi dört yaşındaki annenin ikinci gebeliğinden son adet tarihine göre 31. gebelik haftasında normal vajinal yolla doğan erkek hasta prematürite ve solunum sıkıntısı nedeniyle yenidoğan yoğun bakım ünitesine yatırıldı. Fizik muayenede vücut ısısı $36,3{ }^{\circ} \mathrm{C}$, kalp tepe atımı 159/dk, solunum sayısı 56/dk, oksijen saturasyonu \%92, kan basıncı: 78/57 (63) mmHg, vücut ağırlığı 1600 gr (10-50 persentil), batın distandü, sağda orta hattı geçmeyen karaciğer altından pelvise uzanım gösteren $5 \times 5 \mathrm{~cm}$ boyutlarında kitle mevcuttu. Akciğer grafisi respiratuvar distres sendromu (RDS) ile uyumlu olan hasta surfaktan verildikten sonra nazal CPAP'de izleme alındı. Batındaki kitleye yönelik yapılan ultrasonografik (USG) incelemede sağ sürrenal lojda yer alan, sağ böbreği inferiyora iten ve orta hatta uzanan $6,4 \times 4,6 \times 5,4 \mathrm{~cm}$ boyutlarında yuvarlak-oval konturlu, heterojen hipoekoik, noktasal kalsifikasyonlar içeren iyi sınırlı kitle saptandı. Bilgisayarlı tomografide sağ sürrenal lojda süperiyorda subhepatik düzeyden, inferiyorda pelvik girime kadar uzanım gösteren, sağ böbrekte inferiyora ve mediyale yer değiştirmeye neden olan, sağ böbrekle arasında yağ planı seçilen kistik, nekrotik, lobüle şekilli, kısmen iyi sınırlı, yaklaşık 7×5x6 cm boyutlarında heterojen kitle gözlendi (Resim 1). Mevcut radyolojik bulgularla nöroblastom ön tanısı düşünülen hastanın laboratuvar tetkiklerinde tam kan sayımı, karaciğer ve böbrek fonksiyon testleri normal, serum laktat dehidrogenaz düzeyi (LDH) $393 \mathrm{IU} / \mathrm{L}$, NSE düzeyi $33.3 \mathrm{ng} / \mathrm{ml}(4,7-17 \mathrm{ng} / \mathrm{ml})$, ferritin düzeyi $650 \mathrm{ng} / \mathrm{ml}(20-200 \mathrm{ng} / \mathrm{ml})$, alfa feto protein düzeyi $67707 \mathrm{IU} / \mathrm{ml}$ idi. Postnatal beşinci gününden itibaren oksijen ihtiyacı olmayan hastanın onuncu gününde hipertansiyonu gelişti. Bu dönemde değerlendirilen böbrek fonksiyon testleri ve idrar tetkiki normal, idrarda VMA düzeyi $8,1 \mathrm{mcg} / \mathrm{kg} / \mathrm{kreatinin}(5,9-43,8 \mathrm{mcg} / \mathrm{kg} / \mathrm{kreatinin})$ olarak saptandı. Antihipertansif tedavi olarak nifedipin

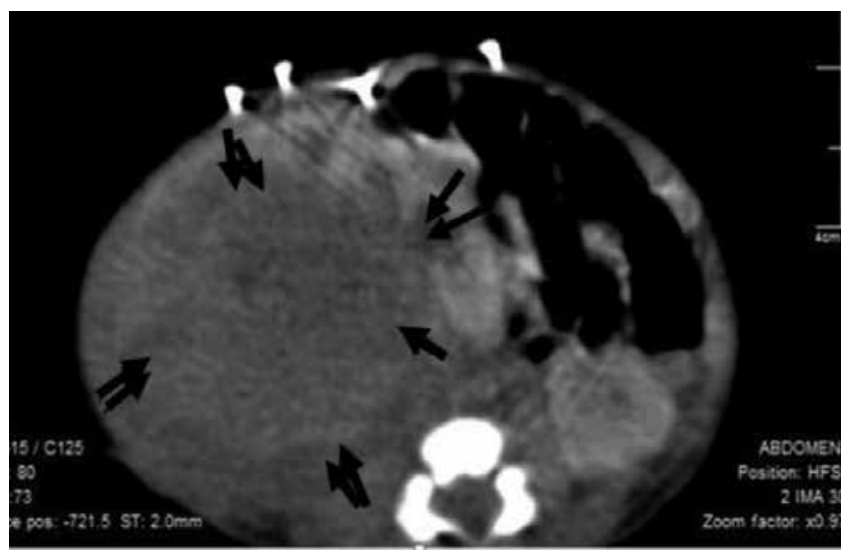

Resim 1. Sağda sürrenal lojda, sağ böbrekte inferiyora ve mediyale doğru itilmeye neden olan (tek ok), süperiyorda subhepatik bölgeye kadar uzanımı izlenen, inferiyorda pelvik girime kadar uzanan dev boyutlarda kistik-nekrotik özellikte kitle lezyonu (çift ok)

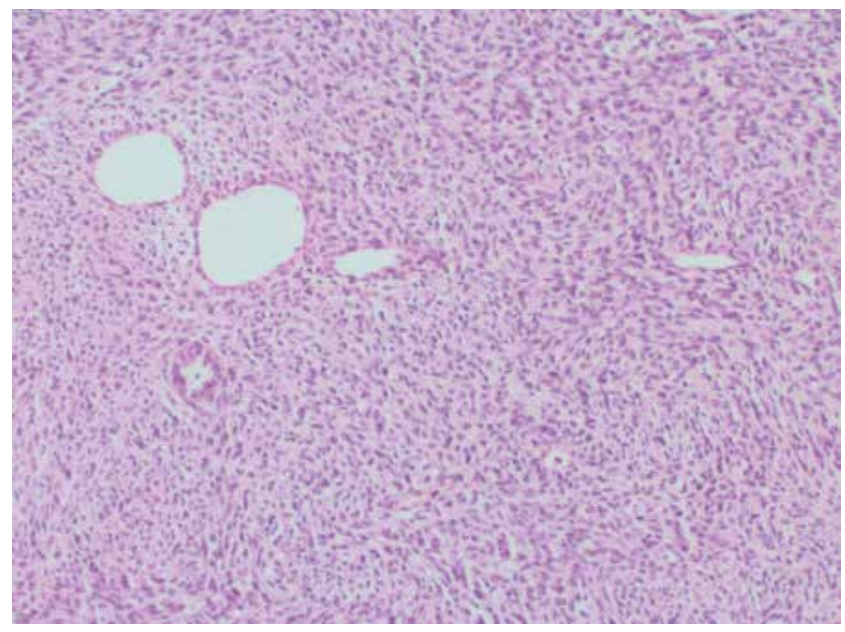

Resim 2. Diffüz gelişim paternine sahip iyi huylu iğsi hücrelerden oluşan neoplazm içinde kalmış tübüler yapılar ve kistik alanlar (H\&E, $\mathrm{x} 100)$ 
başlandı. Kemik iliği aspirasyonunda tutulum saptanmadı. İzlemde serum NSE, ferritin ve idrar VMA düzeylerinde düşüş görülmekle birlikte kontrol batın USG'lerinde kitle boyutlarında artış gözlenen hastaya postnatal 66 . gününde sağ nefroüreterektomi yapıldı. Cerrahi işlem sonucunda sağ böbrekten köken aldığı düşünülen, böbrek dokusunu bozan ve infiltratif özellik gösteren, yer yer kanamalı kistik lezyonlar içeren, lobule kontürlü, yaklaşık $8 \times 10 \mathrm{~cm}$ boyutunda, kirli beyaz renkte kitle eksize edildi. Histopatolojik incelemede infiltratif gelişim paterni gösteren, yer yer kesişen demetler oluşturan, bol mitoz içeren (22-28/10 HPF) mezenkimal hücrelerden oluşan neoplazm, neoplazmın içinde yer yer tübül ve gromerül yapıları, birkaç alanda apopitotik hücre kümeleri, bazı alanlarda kistik ve bir alanda kıkırdak yapısı görüldü (Resim 2). Kitlenin makroskopik ve mikroskopik incelemesi sonucunda selüler tip KMN tanısı kondu. Rezeksiyon sonrası hastanın hipertansiyonu düzeldi ve nifedipin tedavisi kesildi. Hasta, postoperatif beşinci gününde ayaktan izlenmek üzere taburcu edildi. Hastanın en son 12 aylık iken yapılan muayenesinde rekürrens veya metastaz bulgusu saptanmadı. Nöromotor gelişimi yaşıtlarıyla uyumlu bulundu.

\section{Tartışma}

Yenidoğan döneminde görülen neoplastik kitlelerde kesin tanı histopatolojik incelemelerle konulmakla birlikte biyokimyasal testler ve radyolojik görüntüleme yöntemleri ile olası tanı yaklaşımı yapılabilir. Radyolojik olarak kitlenin köken aldığı organ, yayıldığı dokular, karakteri (kistik, solid, kalsifiye, hemorajik vb.), yerleşim yeri (intraperitoneal, retroperitoneal) saptanabilir (6-8). Olgumuzda da ilk klinik bulgu abdominal kitledir. Kitleye yönelik yapılan USG'de saptanan lezyonun ilk aşamada sürrenal kaynaklı gibi görünmesi ve kalsifikasyon içermesi nedeniyle nöroblastom olabileceği düşünülmüştür.

Nöroblastom olguların $\% 65$ 'inde abdominal yerleşimlidir. Sütçocuklarında sürrenal yerleşim sıklığı \%25 iken servikal ve torasik yerleşim daha sıktır (6). Olgumuzda radyolojik bulguların nöroblastomu desteklemesine rağmen eksizyonel biyopsi sonucu yapılan histopatolojik incelemede selüler KMN tanısı konulmuştur.

KMN fetal renal hamartoma ya da leyomyomatoz hamartoma olarak da adlandırılan solid bir renal tümördür $(3,9)$. KMN en sık klinik bulgusu bu yazıda sunulan olguda da olduğu gibi abdominal kitledir. Bazı olgularda tümör hücrelerinden prostaglandin veya parathormon benzeri proteinlerin salınımına bağlı olarak hiperkalsemi görülebilir (10). Olguların birçoğunda polihidramniyoz ve preterm eylem olduğu bildirilmiştir (11). Olgumuz da preterm eylem nedeniyle 31. gebelik haftasında doğmuştur. Daha nadir görülen diğer bulgular hidrops fetalis, tümör rüptürünün neden olduğu hemoperitoneum ve şok, yaygın damar içi pıhtılaşması, konjestif kalp yetmezliği ve hipertansiyondur. KMN'de hipertansiyon görülme sıklığı \%6 olarak bildirilmektedir (3). Hipertansiyonun nedeninin tümör dokusunun glomerüllere basısı ve lokal iskemi sonucunda jukstaglomerüler hücrelerin prolifere olması, buna bağlı olarak renin düzeyinin yükselmesi olduğu ileri sürülmekle birlikte literatürde hiperreninemi sonucu hipertansiyon gelişen çok az sayıda KMN'li yenidoğan olgu bildirilmiştir (12). Olgumuzda da izlem sırasında hipertansiyon saptanmış, serum renin düzeylerine ise bakılamamıştır. Ancak cerrahi eksizyon sonrası hipertansiyonunun düzelmesi olgumuzda hiperreninemi olabileceğini düşündürmektedir.

KMN'de tümör tanısına özgü bir serum belirteci yoktur. Olgumuzda başlangıçta nöroblastom düşünülmesi nedeniyle çalışılan serum NSE düzeyleri yüksek bulunmuştur. NSE, 2-fosfo-D-gliserat-hidrolaz, glikolitik enziminin bir izoenzimidir. Bu enzim santral ve periferik sinir sisteminin nöronal ve nöroendokrin hücrelerinde bulunur. Nöroektodermal kaynaklı tümörlerde serum düzeyi artar. Nöroblastomun tanısı ve izleminde önemli bir belirteçtir (13). NSE'nin makula densa hücreleri, henle kulpunun epitel hücreleri, kalpte iletim sistemi, bronş epitel hücreleri ve Tip 2 pnömositler gibi nonnöronal dokularda da bulunduğu bildirilmiştir (14). Olgumuzda olası hiperreninemiye bağlı hipertansiyon gelişmesi de göz önünde bulundurulursa makula densa hücrelerinden NSE salındığı düşünülebilir.

Serum NSE düzeyleri, nöroektodermal tümörler dışında santral sinir sistemi hasarı yapan durumlarda da artabilir (15). Olgumuza yatışında RDS nedeniyle surfaktan verilmesi ve izleminde mekanik ventilasyon ihtiyacı olması, dolayısıyla hipoksik bir süreçten geçmesi, ayrıca prematüreliğe bağlı hemato-ensefalik bariyerin olgunlaşmaması nedeniyle serum NSE düzeyleri yüksek saptanmış olabileceği akla gelmektedir.

Olgumuzun başlangıçta yüksek olan serum NSE düzeyleri seri izlemlerinde giderek düşmüştür. Bir çalışmada kafa travması olan hastalarda başlangıçta serum NSE düzeyleri yüksek saptanmış, seri ölçümlerde iyileşen olgularda serum NSE düzeylerinin azaldığı gösterilmiş, buna göre NSE'nin seri ölçümlerinin nöronal hasarın belirlenmesinde kullanılabileceği ileri sürülmüştür (16).

KMN'de tümör genellikle renal kapsülle çevrilidir, fakat tümör-renal parankim sınırı düzensizdir. Renal parankime yayılan, perirenal yağ dokusunu infiltre eden büyüme paterni gösterir. Histolojik olarak klasik ve atipik (selüler) olmak üzere iki formu tanımlanmıştır. Klasik form, bir kaç mitoz içeren, orta derecede selülerite gösteren, birbirini çaprazlayan gevşek bantlar yapmış iğsi hücrelerden oluşur. KMN selüler formu klasik formunun aksine lokal rekürrens, akciğer ve beyine metastaz yapma potansiyeline sahiptir. 
Daha agresif olan bu formda; nekroz, hemoraji, belirgin selülarite ve yüksek mitotik indeks bulunur (17). KMN olgularının çoğu, ister klasik, ister selüler olsun, sadece kitle rezeksiyonu veya nefrektomi ile tedavi edilebilir $(3,18)$. Literatürde seçilmiş olgularda selüler KMN'nin cerrahi tedavisi yanında kemoterapi uygulandığı bildirilmektedir (3). Olgumuzda cerrahi rezeksiyon sonrası kür sağlandı, hipertansiyon geriledi, postnatal 12 aylık izlemde lokal rekürrens veya metastaz bulgusu saptanmadı.

Sonuç olarak yenidoğan döneminde radyolojik olarak nöroblastom düşündüren kitle varlığında serum NSE düzeylerinin yüksek saptanması yanıltıcı olabilir. Tanıda histopatolojik inceleme çok önemlidir. Özellikle hipertansiyonu olan olgularda KMN'de olabileceği akılda tutulmalıdır.

\section{Kaynaklar}

1. Wootton SL, Rowen SJ, Griscom NT. Pediatric case of the day. Congenital mesoblastic nephroma. Radiographics 1991;11:719-21.

2. Bolande RP, Brough AJ, Izant RJ Jr. Congenital mesoblastic nephroma of infancy. A report of eight cases and the relationship to Wilms' tumor. Pediatrics 1967;40:272-8.

3. Isaacs H Jr. Fetal and neonatal renal tumors. J Pediatr Surg 2008;43:1587-95.

4. Miller OF, Kolon TF. Hyperreninemia and congenital mesoblastic nephroma: case report and review of the literature. Urology 2000;55:775.

5. Saurabh K, Yadav R, Sharma S, Gupta R. Congenital mesoblastic nephroma: A rare cause of recurrent hematuria beyond infancy. Indian J Nephrol 2013;23:322-3.

6. Brodeur GM, Maris JM. Neuroblastoma. In Pizzo P, Poplack DG , editors. Principles and Practice of Pediatric Oncology. Philadelphia: Lippincott-Raven; 2006;933.

7. Sandoval JA, Hoelz DJ, Woodruff HA, et al. Novel peptides secreted from human neuroblastoma: useful clinical tools? J Pediatr Surg 2006;41:245-51.
8. Brossard J, Bernstein ML, Lemieux B. Neuroblastoma: an enigmatic disease. Br Med Bull 1996;52:787-801.

9. Furtwaengler R, Reinhard H, Leuschner I, et al. Mesoblastic nephroma-a report from the Gesellschaft fur Pädiatrische Onkologie und Hämatologie (GPOH). Cancer 2006;106:227583.

10. Glick RD, Hicks MJ, Nuchtern JG, Wesson DE, Olutoye OO, Cass DL. Renal tumors in infants less than 6 months of age. J Pediatr Surg 2004;39:522-5.

11. Leclair MD, El-Ghoneimi A, Audry G, at al. The outcome of prenatally diagnosed renal tumors. J Urol 2005;173:186-9.

12. Siemer S, Lehmann J, Reinhard $H$, et al. Prenatal diagnosis of congenital mesoblastic nephroma associated with renal hypertension in a premature child. Int J Urol 2004;11:50-2.

13. Cangemi G, Reggiardo G, Barco S, et al. Prognostic value of ferritin, neuron-specific enolase, lactate dehydrogenase, and urinary and plasmatic catecholamine metabolites in children with neuroblastoma. Onco Targets Ther 2012;5:417-23.

14. Haimoto H, Takashi M, Koshikawa T, Asai J, Kato K. Enolase isozymes in renal tubules and renal cell carcinoma. Am J Pathol 1986;124:488-95.

15. Herrmann M, Curio N, Jost S, et al. Release of biochemical markers of damage to neuronal and glial brain tissue is associated with short and long term neuropsychological outcome after traumatic brain injury. I Neurol Neurosurg Psychiatry 2001;70:95-100.

16. Celtik C, Acunaş B, Oner N, Pala O. Neuron-specific enolase as a marker of the severity and outcome of hypoxic ischemic encephalopathy. Brain Dev 2004;26:398-402.

17. Bayindir P, Guillerman RP, Hicks MJ, Chintagumpala MM. Cellular mesoblastic nephroma (infantile renal fibrosarcoma): institutional review of the clinical, diagnostic imaging, and pathologic features of a distinctive neoplasm of infancy. Pediatr Radiol 2009;39:1066-74.

18. England RJ, Haider N, Vujanic GM, et al. Mesoblastic nephroma: a report of the United Kingdom Children's Cancer and Leukaemia Group (CCLG). Pediatr Blood Cancer 2011;56:744-8. 